\title{
Literatura łagrowa i lagrowa - ku interdyscyplinarnej definicji gatunku
}

\author{
Marek PĄKCiński \\ (Instytut Badań Literackich PAN, Warszawa)
}

I.

Obecnie dobrze znane i powszechnie akceptowane jest twierdzenie, że epoka nowoczesności doprowadziła do radykalnej zmiany uwarunkowań ludzkiej percepcji, a także rozumienia tego, co jest ogólnie uznawane za „rzeczywistość”. Zmieniły się nie tylko najbliższe jednostce społeczne ramy naszego bytowania (w tej sferze doszło przede wszystkim do zjawiska określanego mianem „upadku rodziny”, która została wyparta $\mathrm{z}$ roli podstawowego regulatora zachowań ludzkich przez mechanizmy państwa i rynku), lecz także zakres możliwych doświadczeń człowieka. Zmiany te - jak zgodnie stwierdza większość komentatorów - mają skalę przekraczającą wszystko, co w dziejach gatunku ludzkiego zdarzyło się dotychczas.

Bez wątpienia szeroko rozumiany fenomen obozu koncentracyjnego lub obozu pracy (zarówno nazistowskiego, jak i stalinowskiego) stanowił mroczne, negatywne ekstremum cywilizacyjno-kulturowego procesu nowoczesności, a zarazem jeden z najbardziej radykalnych przejawów mentalnej „rewolucji”, do której doprowadziła ta epoka. Pojawia się zatem pytanie, czy literatura będąca zapisem tych doświadczeń ma jakieś szczególne, identyfikowalne cechy, które mogłyby wyróżnić ją na tle innych form prozatorskich (w tym także literatury faktu we wszelkich jej przejawach)? Jeśli zaś odpowiedź na to pierwsze pytanie byłaby twierdząca, to czy możliwe jest, że te cechy genologiczne mogłyby wiązać się z poznaniem rzeczywistości obozowej przez bohatera tego typu literatury i ze szczególnymi doznaniami lub spostrzeżeniami, które stają się jego udziałem? Można, jak sądzę, postawić tu wstępną hipotezę, że ciekawą perspektywę wyróżnienia literatury ła-

1 Takiego sformułowania używa m.in. Yuval Noach Harari, autor popularnej książki Sapiens. Od zwierząt do bogów (tłum. J. Hunia, Warszawa 2017). 
growej i lagrowej na tle świadectw doświadczeń granicznych w literaturze stwarza kognitywistyka, wraz z jej wciąż poszerzającym się zasobem pojęć dotyczących ludzkich procesów poznawczych oraz granic ich możliwości².

Kluczem do zdefiniowania na nowo literatury łagrowej i literackich świadectw dotyczących obozów koncentracyjnych byłaby zatem nie jakaś jej cecha formalna lub genologiczna, lecz sam jej główny temat: „człowiek zlagrowany” (termin ukuty przez Tadeusza Borowskiego w jego opowiadaniach o Auschwitzu), transformacja jego kompetencji poznawczych i zmiana jego psychiki wywołana przez te doświadczenia. Można zaryzykować twierdzenie, że tego typu literatura jest w głębokim sensie humanistyczna, ponieważ obszar jej zainteresowań obejmuje nie tylko sferę doświadczenia ludzkiego, ale również to, co wobec niej zewnętrzne, co zdawało się wcześniej niewyrażalne lub było poznawczym „skandalem”. Pełną świadomość tego miał Warłam Szałamow, gdy pisał:

\Po zaszłościach zostaje dokument, ale nie jest to zwykły dokument, lecz jak Opowiadania kotymskie dokument zaprawiony emocjami. Taka proza - to jedyna forma literatury, która może usatysfakcjonować czytelnika XX wieku.

Po wtóre, przedstawiłem tu ludzi w szczególnie ważnym i wyjątkowym, nieopisywanym dotąd stanie, zbliżonym do stanu spoza - człowieczeństwa [...]. Moja proza przechowuje szczątki, jakie ocalały w człowieku. Czymże są te pozostałości? Czy leżą one na nieprzekraczalnej granicy, czy poza nią istnieje już tylko śmierć - duchowa i fizyczna? W tym sensie moje opowiadania można uznać za szkic [...], ale nie taki, jak Zapiski z martwego domu, lecz eksponujący osobowość autora, zresztą w ogóle nie ma artysty bez osobowości, indywidualnego punktu widzenia. Opowiadania to moja dusza, mój punkt widzenia, własny, tzn. jednostkowy. Na tym jednostkowym punkcie widzenia trzyma się nie tylko literatura piękna. Nie ma pamiętników - są pamiętnikarze ${ }^{3}$.

Szałamow zdaje się sugerować w tym fragmencie swoich zapisków, że związek pisanej przez niego literatury łagrowej z osobowością i indywidualnością twórcy

2 Szczególne miejsce kognitywistyki jako narzędzia wspomagającego nauki humanistyczne spowodowane jest przez fakt, że - w odróżnieniu od innych teorii ludzkich procesów poznawczych, np. epistemologii genetyczno-strukturalnej Jeana Piageta - w znacznym stopniu uwzględnia ona rolę emocji w tych procesach, co czyni ją szczególnie przydatną np. dla literaturoznawstwa.

3 W. Szałamow, Nowa proza. Zapiski z lat siedemdziesiątych („Nowyj mir” 1989, nr 12, s. 3, wydała I. P. Sirotinskaja), tłum. I. Migal, ,Teksty Drugie” 2009, nr 5, s. 206. 
ma odmienny charakter niż w przypadku innych świadectw literackich ${ }^{4}$ Nie można tu bowiem mówić o jakichś wstępnych założeniach poznawczych, które mogłyby kształtować stosunek piszącego podmiotu do opisywanego materiału przeżyć i spostrzeżeń. Drugą ważną cechą tych relacji jest ich paradoksalność, polegająca na przedstawianiu deformacji i rozpadu osobowości (piszącego) równolegle z prezentowaniem tego, co zwykliśmy nazywać rzeczywistością obiektywną, zewnętrzną wobec poznającego podmiotu.

Do ważnych cech takiego podejścia należałoby z jednej strony współtworzenie spojrzenia na gułag i nazistowskie obozy koncentracyjne z szerszej perspektywy, pozwalającej na uogólnienia (na nieco innej podstawie poznawczej niż kategoria doświadczenia granicznego), a $z$ drugiej - na powiązanie tego typu literatury i zawartych w niej rozpoznań z nowoczesnością jako epoką wielowymiarowego kryzysu człowieczeństwa. W szczególności zaś, korzystając z podobnego podejścia, można byłoby połączyć (nie tylko na osnowie pojęć krytycznoliterackich, takich jak np. groteska) twórczość doby gułagu i obozów koncentracyjnych z niepokojąco do niej podobnymi utworami z lat dwudziestych i trzydziestych XX wieku (np. parabole Franza Kafki, proza Roberta Musila czy Michaiła Bułhakowa). Byłoby to sensowne oczywiście tylko w przypadku, gdyby prowadziło do płodnych poznawczo wniosków przez ukazanie pokrewnego w obu przypadkach doświadczenia ludzkiego reprezentowanego w tej twórczości.

\section{2.}

Dlaczego właśnie kognitywistyka miałaby być kluczową perspektywą interpretacyjną przyjmowaną wobec literatury lagrowej i łagrowej? Otóż ten kierunek badawczy charakteryzuje się ścisłym związkiem pomiędzy kategoriami psychologicznymi a semiotycznymi (stanowiącymi przedmiot kulturoznawstwa), a także pojęciami biologicznymi, sytuującymi człowieka w kontekście zjawisk przyrody, konkretnie zaś w świecie zwierzęcym, wśród pokrewnych mu gatunków. Tym samym wydaje się on szczególnie predestynowany do interpretacji zjawisk z pogranicza życia i śmierci, umieszczających człowieka w „socjaldarwinowskim" kontekście, w który rzuciła go sama nowoczesność. Jak pisze

4 Trudno np. byłoby mówić - w moim przekonaniu - z pełną wiarygodnością o realizmie czy też naturalizmie tego typu prozy (mimo że spośród istniejących wcześniej kierunków literackich właśnie te dwa byłyby literaturze łagrowej i lagrowej najbliższe). W wielu wypadkach kategorie związane z literackimi prądami mogą być nadane tego rodzaju świadectwom dopiero ex post i ze znacznie mniejszą dozą pewności niż w przypadku twórczości niedotykającej sfery doświadczeń granicznych (np. kategoria naturalizmu wiązana zwykle z twórczością Tadeusza Borowskiego). 
kognitywista Dan Sperber w swojej książce Rozumienie kultury. Podejście naturalistyczne:

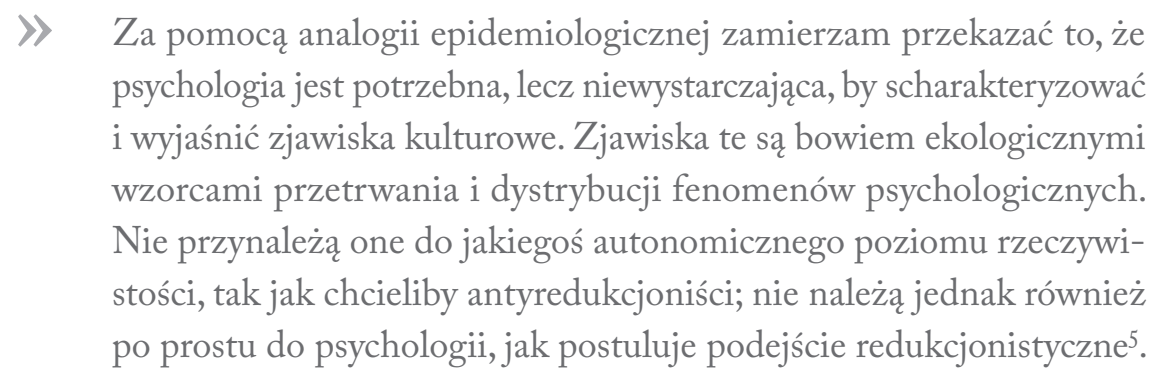

Zaproponowane tu podejście, zwane przez Sperbera „epidemiologią reprezentacji”, wydaje się użyteczne do badania antropologiczno-kulturowych zjawisk doby totalitaryzmu choćby ze względu na fakt, że fenomeny te już wcześniej opisywano, stosując intuicyjnie medyczną czy też epidemiologiczną metaforykę. $\mathrm{O}$ „zarażeniu totalitaryzmem”, „totalitarnej chorobie” czy też nowoczesnym autorytaryzmie jako „nowotworowej narośli” na społecznym organizmie pisano tak często, że tego typu metaforyka stała się właściwie obiegowym miejscem wspólnym posttotalitarnego literaturoznawstwa i krytyki. Postulowany przez Dana Sperbera ścisły związek semiotyki reprezentacji kulturowych i psychologii również znajduje potwierdzenie w podkreślanej w cytowanych już zapiskach Warłama Szałamowa szczególnej relacji pomiędzy „tekstem obozowym” a jego autorem. Głęboko i w szczególnym sensie osobisty charakter tych relacji - zwłaszcza w przypadku najwartościowszych artystycznie przejawów prozy obozowej - jest wyraźnie widoczny nawet po dość powierzchownym porównaniu świadectw Aleksandra Sołżenicyna, Warłama Szałamowa, Primo Leviego czy Imre Kertésza. Mimo pewnych uderzających analogii pomiędzy organizacją nazistowskich i sowieckich obozów śmierci relacje te są w pewien elementarny sposób różne, nawet jeśli dotyczą tych samych

5 D. Sperber, Explaining culture. A naturalistic approach, Oxford 2005, s. 60. (Jeśli nie zaznaczono inaczej, przekład wszystkich cytatów w prezentowanym tekście pochodzi od autora artykułu).

Wymieniona w cytacie analogia epidemiologiczna polega na sformułowanej w tej książce Sperbera propozycji potraktowania reprezentacji kulturowych (a zwłaszcza tzw. metareprezentacji, czyli przedstawień innych reprezentacji, zakorzenionych w innych ludzkich umysłach) jako zjawisk egzystujących i rozpowszechniających się w ludzkich mózgach, podobnie jak epidemie w organizmach danej populacji. Wiąże się to z naturalistycznym (czy też nawet materialistycznym, jak pisze autor) podejściem Sperbera do semiotyki zjawisk kultury, które jego zdaniem nie pokrywają się nigdy z jakimś „idealnym modelem” tekstu kultury (tak jak np. w semiotyce strukturalistycznej), lecz zawsze są konkretnymi realizacjami (czy to stanami energetycznymi neuronowych sieci w ludzkich mózgach, czy też wygłoszonymi lub zapisanymi wypowiedziami o konkretnych cechach fizycznych, jeśli są to „reprezentacje publiczne”). W sprawie definicji metareprezentacji zob. L. Cosmides i J. Tooby, Rozważanie źródet - o ewolucji ludzkich zdolności adaptacyjnych do segregowania informacji i tworzenia metareprezentacji, w: Metareprezentacje. Perspektywa interdyscyplinarna, red. D. Sperber, Oxford 2000, s. 75. 
miejsc kaźni (np. Wyspy Sołowieckie, Auschwitz, Buchenwald, Kołyma) ${ }^{6}$. Można w tym miejscu zaryzykować stwierdzenie, że ów indywidualny charakter opowieści określany jest przez sposób, w jaki osobowość doświadczającej jednostki ludzkiej ulega rozpadowi, a następnie względnej, warunkowej, prowizorycznej reintegracji na poziomie tekstu (w postaci autora-bohatera opowieści), choć nie w rzeczywistości obozowej.

Kluczowym argumentem na rzecz zasadności zastosowania metodologii kognitywistycznej do badania świadectw z gułagu i obozów koncentracyjnych jako symptomów cywilizacji nowoczesnej jest jednak możliwość wyjaśnienia tego, w jaki sposób w obu tych totalitarnych instytucjach doprowadzono do odsłonięcia archaicznego podłoża ludzkiej kultury i indywidualnej psychiki poszczególnych jednostek. Następnie zaś ów elementarny grunt ludzkiego doświadczenia był niwelowany w celu nadania mu nieznanych dotychczas, eksperymentalnych form i właściwości. Jednym z zabiegów służących destrukcji cywilizacyjnych form (który stanowił efekt uboczny zbrodniczego pragmatyzmu gułagu) było przywrócenie instytucji niewolnictwa wraz z praktyką egzekwowania władzy nad życiem i śmiercią innych ludzi. Jak pisał Sołżenicyn:

\ W tych latach, kiedy akta więźniów nie były opatrzone zawczasu skierowaniami, zborniaki zamieniały się w targowiska niewolników. Najbardziej pożądanymi gośćmi stali się tam nabywcy i słowo to coraz częściej wypowiadane było w korytarzach i w celach bez żadnego uśmiechu. $\mathrm{W}$ całym przemyśle nikt nie chciał już czekać, aż przyślą $\mathrm{mu}$ surowce lub siłę roboczą $\mathrm{z}$ centrum według rozdzielnika, więc posyłało się specjalnych popychaczy i pełnomocników. Tak samo było w GUŁagu: tubylcy na poszczególnych wyspach wymierali. Chociaż nie kosztowali ani grosza, ale trzeba było ich mieć i dlatego musiało się samemu ich zdobyć, aby obóz mógł wykonać plan. Nabywcy musieli

6 Jeśli chodzi o porównanie „zewnętrznego”, organizacyjnego aspektu gułagu i nazistowskich obozów koncentracyjnych, Aleksander Sołżenicyn pisał następująco (na temat obozów na Wyspach Sołowieckich): „Nowicjusz upada na duchu zanim jeszcze zdąży wejść na serio w sołowieckie życie i zacząć swoje bezkresne trzy lata odsiadki. Ale współczesny czytelnik grubo by się pomylił wyciągając przedwcześnie oskarżycielski palec: oto właśnie system zagłady, to jest obóz śmierci! E, to nie takie proste! W tej pierwszej zonie, eksperymentalnej, jak zresztą w następnej, a nawet w ostatniej - największej ze wszystkich - zonie GUŁagu, nie działamy wcale otwartym chwytem, stosujemy system wielowarstwowy - i dlatego tyle mamy sukcesów, dlatego to trwa tak długo" (A. Sołżenicyn, Archipelag GUŁag. 1918-1956, tłum. J. Pomianowski (pseud. Michał Kaniowski), wyd. 14, Poznań 2018, s. 371). Jak widać, zdaniem Sołżenicyna różnica pomiędzy nazistowskim obozem śmierci a gułagiem polegałaby na bardziej eksperymentalnym charakterze tego ostatniego; gułag był miejscem, gdzie rzeczywiście przed uśmierceniem więźnia, które w wielu przypadkach było nieuniknione, oprawcy i nadzorcy z NKWD próbowali stworzyć z niego „nowego człowieka” (jakkolwiek ta nowa konstrukcja charakterologiczna nie miała nic wspólnego z oficjalnie głoszonymi przymiotami „człowieka radzieckiego”). 
być ludźmi bystrymi, spostrzegawczymi, aby widzieć, jaki towar im się daje i nie pozwolić sobie wkręcić jakichś półtrupów albo inwalidów?

Widać tu, w jaki sposób stworzona przez epokę nowoczesności wolność działania w zakresie „społecznej inżynierii” zaowocowała faktycznym powrotem do archaicznych praktyk socjalno-ekonomicznych. Rozpoznanie skali owego powrotu - w którym odtworzono wszystko to, co już myślicielom Oświecenia wydawało się bezpowrotnie przebrzmiałe - stało się udziałem więźniów gułagu i nazistowskich obozów koncentracyjnych. Natomiast na możliwość zjawienia się w historii dotychczas niespotykanej wolności działania partyjno-militarnych „elit”, która rodzi zniewolenie dla wielkich rzesz ludzkich, zwracali uwagę już dziewiętnastowieczni twórcy kultury (na myśl przychodzi tu przede wszystkim Dostojewski ze słynną frazą z Braci Karamazow: „Jeżeli Boga nie ma, wszystko wolno” oraz oczywiście jako autor Biesórw). Tak pisze o niej Sołżenicyn:

》 Tylko siekierka! Żerdki! Komary! Włóczenie po karczowisku! Rozwałka w biały dzień! Moskwa śle transporty nie licząc się z lokalnymi kadrami - ale Moskwa też nie krępuje swoich czekistów żadnymi obłudnymi przepisami: wszystko co robią dla utrzymania ładu - jest godne uznania $\mathrm{i}$ istotnie żaden prokurator nie dotknął stopą sołowieckiej ziemi ${ }^{8}$.

Wolność katów - odwrotnie proporcjonalna do zniewolenia więźniów - była tym większa, im bardziej wykraczała poza wszelkie zasady oraz pisane i niepisane obyczaje przyjęte przez homo sapiens $\mathrm{w}$ toku jego ewolucji. Śledczy, nadzorcy i organizatorzy terroru byli w stanie - na mocy patronującej im teorii oraz przyznanego zakresu władzy - zniweczyć normy stosowane dotychczas przez ludzkość, w tym również te najbardziej pragmatyczne i oczywiste, bo podyktowane przez instynkt samozachowawczy. Oddajmy znów głos autorowi Archipelagu GUŁag, który następująco pisze o wyniszczeniu chłopów w ZSRS:

》 tych chłopów, którzy w I928 roku nakarmili jeszcze całą Rosję swoim chlebem - rugują miejscowe niezguły i przyjezdni miastowi ludzie.

7 A. Sołżenicyn, op. cit., s. 324. „Zborniaki” to nazwa więzień i obozów przejściowych (takich jak np. w Moskwie na Krasnej Presni, w Irkucku lub w Błagowieszczeńsku), z których więźniowie kierowani byli do różnych obozów na Dalekiej Północy w celu wykonywania tam niezmiernie ciężkiej, niewolniczej pracy (np. Kołyma, Sachalin, Wyspy Sołowieckie).

8 A. Sołżenicyn, op. cit., s. 373-374; „siekierka”, „żerdki”, „komary” i „włóczenie po karczowisku” to nazwy różnych tortur (najczęściej kończących się śmiercią skazanego), stosowanych wobec więźniów przez oprawców z NKWD. 
Jakby ich bies opęta1, jakby wyzbyli się wszelkich, ludzkich uczuć i ludzkich obyczajów, utrzymujących się przez tysiąclecia - zaczęli najlepszych rolników łapać hurmem, razem z rodzinami i bez żadnego mienia, gołych wyganiać na północne pustynie, w tundry, do tajgi ${ }^{9}$.

W ten sposób „totalitarna elita” kontestowała cywilizacyjne praktyki, które współczesna antropologia pojmuje jako przejmowane z pokolenia na pokolenie i usankcjonowane obyczajem sekwencje działań, w tym wypadku związane z szacunkiem wobec żywicieli zbiorowości. Całkowite odrzucenie zasad prawa (stosowanego w Rosji od dawna w wersji autorytarnej, zdeformowanej przez biurokratyczne rządy) odbyło się już wcześniej, a z ogniw procesu sądowego pozostały właściwie tylko dwa: prokurator i kat (ten ostatni - wcielony w machinę „czerwonego terro$\mathrm{ru}^{\text {"'o }}$ ). Zachowanie pozornej, proceduralnej formy legalnych praktyk przy jednoczesnym zerwaniu związku z ich źródłami w sferze prawnego ładu skutkuje powstaniem rzeczywistości groteskowej, zdeformowanej, która poddaje poznawcze władze człowieka nieustannym wstrząsom. To właśnie dzięki takiej szokowej „obróbce” świadomości podsądnego śledczy i nadzorcy mogli dowolnie wykorzystywać ludzką tendencję do ustanawiania normalności, do pozostawania w sferze mediacji i dialogu, w której świat mimo wszystko nie jest pozbawiony sensu; skłonność ta zdaniem Michaela Wooda stanowi również istotę poznawczego aspektu twórczości Franza Kafki, decydując o powieściowych biografiach jego bohaterów ${ }^{\mathrm{II}}$. $\mathrm{Na}$ podobny, surrealistyczny aspekt swojego losu zwraca uwagę Sołżenicyn, podsumowując wiele lat obozowego życia:

9 Ibidem, s. 40.

10 Jak pisał (w gazecie „Krasnyj terror”) jeszcze w listopadzie 1918 r. cytowany przez Sołżenicyna teoretyk „czerwonego terroru” Martyn Łacis: „Nie wojujemy z poszczególnymi osobnikami. Likwidujemy burżuazję jako klasę. W czasie śledztwa nie szukajcie materiałów i dowodów mających wykazać, że oskarżony czynem albo słowem walczył przeciw władzy Rad. Pierwsze pytanie, jakie powinniście mu zadać, to - do jakiej klasy się zalicza, jakiego jest pochodzenia, jakie ma wykształcenie, jaki zawód. Te kwestie powinny właśnie decydować o losie oskarżonego. Na tym polega sens i treść czerwonego terroru" (ibidem, s. 24). Kluczową zasadą odpowiedzialności w państwie totalitarnym jest zatem odpowiedzialność nie za czyny, lecz za to, kim się jest. Pytanie, które można w związku z tym rozważyć, polegałoby na zasięgu tego typu odpowiedzialności w systemach represyjno-prawnych społeczeństw doby nowoczesności. Czy rzeczywiście narzucanie takiej odpowiedzialności było wyłącznie domeną państw totalitarnych, a tendencja do niszczenia tożsamości tych, których samoidentyfikacja zdawała się niewygodna dla dysponentów władzy, nie okazała się w nowoczesności zjawiskiem de facto szerszym niż powszechnie sądzimy?

11 Jak stwierdzał Michael Wood, Kafkowski obraz świata „sprowadza się [...] do desperackiej próby rekonstrukcji zwykłości, do normalności postrzeganej jako ostateczny warunek przetrwania. U Kafki jest tak, jakby pojęcie «tego co zwykłe» nie mogło zostać porzucone, niezależnie od tego, jaki kształt owa normalność przybierze" (zob. M. Wood, Literature and the Taste of Knowlegde, Cambridge - New York 2005, s. 74). 
\Gęstą trawą zarosła mogiła mojej młodości. Mam już za sobą cały termin kary i nawet bezterminowe zesłanie. I nigdzie, ani w „kulturalno-wychowawczych" oddziałach obozów, ani w bibliotekach rejonowych, ani nawet w miastach średniej wielkości nigdzie, powtarzam, nie widziałem na oczy, nie trzymałem w ręku, nie mogłem kupić, pożyczyć, ani nawet POPROSIĆ O POKAZANIE kodeksu sowieckich praw! I setki moich znajomych więźniów, z doświadczenia wiedzących coś o śledztwie, sądzie, a nierzadko też - o obozach i zesłaniu - otóż nikt $\mathrm{z}$ nich nie widział kodeksu i nie miał go w ręku! $!^{\text {I2 }}$

To ostatnie zdanie, które z powodzeniem mogłoby stanowić fragment opowiadania lub powieści Kafki (lub też utworu pisarza „modelowego” dla postmodernizmu - Jorge Luisa Borgesa) dowodzi skali i gruntownego charakteru podjętego $\mathrm{w}$ „zenicie” nowoczesności eksperymentu z człowiekiem. Dwie cechy systemu represji: płynność zasad i przygodność kar decydowały o jego prawdziwie „eksperymentalnym" charakterze. Zgodnie z doktryną prokuratora generalnego ZSRS Andrieja Wyszinskiego, skoro odkrywana przez śledztwo prawda jest zawsze względna, względne mogą być również materiały gromadzone przez śledczych dla potwierdzenia winy podsądnego (były to dowody, które można uzyskać przez rozumowanie indukcyjne $\mathrm{w}$ gabinecie funkcjonariusza organów ścigania, a nie za sprawą dedukcji - w miejscu, gdzie przestępstwo zostało popełnione ${ }^{\mathrm{r} 3}$.

W obu tych historycznych fenomenach (tj. gułagu i nazistowskich Konzentrationslagern) wyraża się możliwość potraktowania podstaw moralnego i praktycznego ładu życia społeczeństw jako zjawisk całkowicie przygodnych, a tym samym kształtowania ich w zależności od doraźnych i subiektywnych potrzeb lub zapatrywań reprezentantów władzy. Twórcy obu systemów faktycznie udowodnili, że mogą zostać podeptane i anulowane elementarne zasady rządzące dotychczas ludzkim życiem i że na tej podstawie stworzyć można pozorny ład, ufundowany na przekroczeniu wszelkich norm, który będzie praktycznie funkcjonował, a nawet pod pewnymi względami i w ograniczonym czasie przewyższał tradycyjne społeczeństwa efektywnością (zwłaszcza w warunkach militarnego konfliktu).

Jaskrawym przykładem takiej przygodności może być absolutne zrównanie populacji ludzi „niewinnych” $i$,winnych” (a tym samym „wolnych” $i$,uwięzionych/ ukaranych") w stalinizmie epok Jeżowa i Berii - o czym pisze Warłam Szałamow ${ }^{\text {T4 }}$

12 A. Sołżenicyn, op. cit., s. 75.

13 Zob. ibidem, s. 64.

14 Jak pisał Szałamow: „W łagrach nie było politycznych. Byli tylko urojeni, wymyśleni wrogowie, z którymi jednakże państwo rozliczało się jak z prawdziwymi wrogami - rozstrzeliwało, zabijało, morzyło głodem. Stalinowska kosa śmierci cięła wszystkich bez różnicy, opierając się na rozdzielnikach, spisach i wykonaniu 
- lub funkcjonująca w nazizmie bezwzględna polityczna instrumentalizacja nauki (szczególnie antropologii fizycznej i antropometrii) w celu realizacji utopijnych, rasistowsko-imperialnych zamierzen ${ }^{15}$. W tym ostatnim przypadku zatem pozorna prawda naukowa (decydująca o masowej zagładzie lub przetrwaniu ludzi o określonych cechach fizycznych, realnych lub nie) była arbitralnie określona i w pełni podporządkowana doraźnej polityce.

\section{3.}

Kognitywistyka, mimo rozważania problemów ludzkiej kultury na tle biologicznych uwarunkowań i zdolności homo sapiens, sformułowała wiele znaczących tez dotyczących wyjątkowości człowieka pośród innych gatunków przyrodniczych. W ujęciu Dana Sperbera i innych kognitywistów zajmujących się kulturowymi reprezentacjami do takich kluczowych własności należy zdolność zbierania i gromadzenia dużej ilości różnych informacji, które przedstawicielom naszego gatunku nie przydają się bezpośrednio do rozwiązania doraźnych problemów przetrwania w środowisku' ${ }^{16}$. Pod tym właśnie względem - twierdzą kognitywiści, popierając to badaniami eksperymentalnymi - człowiek w istotny sposób różni się od innych zwierząt, w tym także od naczelnych.

Jednakże tak określony „przywilej” człowieka ma również swoją negatywną stronę. Jak piszą antropolodzy kognitywni Leda Cosmides i John Tooby:

\section{\Dla przedstawiciela gatunku w nieuchronny sposób zależnego od in- formacji, z których znaczna część dostarczana jest przez innych ludzi, odpowiedź na pytanie, czy można na nich polegać, jest kwestią życia}

planu. Pośród tych, co zginęli w łagrze, był taki odsetek niegodziwców i tchórzy co na wolności. Wszystko to byli ludzie przypadkowi - spośród obojętnych, tchórzy, zwykłych obywateli, a nawet spośród katów wszystkich ich przypadek uczynił ofiarami.

Łagier był dla człowieka wielką próbą siły charakteru, zwykłej ludzkiej moralności i dziewięćdziesiąt dziewięć procent ludzi nie wytrzymywało tej próby. Wraz z tymi, co nie wytrzymali, umierali ci, co zdołali wytrzymać starając się być lepszymi niż wszyscy, twardszymi dla samych siebie...” (W. Szałamow, Inżynier Kisielow, w: idem, Opowiadania kotymskie, t. 2 Artysta topaty, tłum. J. Baczyński, Poznań 2017, s. 278).

15 W sprawie instrumentalizacji nauk o człowieku przez nazistowską dyktaturę w Niemczech lat trzydziestych XX wieku zob. A. Tyrowicz, Światto wiedzy zdeprawowanej: idee niemieckiej socjologii i filozofii (1933-1945), Kraków 2009.

16 Przyczyną tego jest oczywiście duży rozmiar i chłonność ludzkiego mózgu. Informacje te są w nim, zdaniem antropologów kognitywnych, zbierane, archiwizowane, wyposażane w określone „znaczniki” (tags), określające ich źródło, wiarygodność, zasięg, ważność, termin przydatności do wykorzystania itd., a następnie - w miarę potrzeb - używane w nowych sytuacjach życiowych. 
i śmierci. [...] Ocena wiarygodności informacji jest szczególnie ważna podczas skomplikowanej sztuki nawigacji po świecie społecznym ${ }^{\mathrm{I}}$.

Oczywiście gatunek ludzki wypracował wiele potencjalnych barier i zabezpieczeń przed ewentualnymi nadużyciami kognitywnej zdolności człowieka, która oznacza zarazem informacyjną zależność od innych ludzi. Warto jednak zwrócić uwagę na fakt, że ten obszar poznawczej niepewności powstaje nie tylko w wyniku świadomego nadużycia języka - czyli zwykłego, prostego kłamstwa. Cosmides i Tooby komentują to następująco:

》 Głównym motorem, który popchnął człowieka ku jego wyjątkowej ścieżce ewolucyjnej, mógł być wybór odpowiedniego mechanizmu spekulatywnego [computational machinery - M. P.] pozwalającego naszemu gatunkowi wkroczyć w coś, co określiliśmy mianem „niszy poznawczej”. Chodzi tu o mechanizm, który radykalnie zwiększył naszą możliwość zdobywania i wykorzystywania informacji o charakterze lokalnym, przejściowym i przygodnym, po to, by wyciąać z nich wnioski, co z kolei pozwala na opracowywanie planów działania i nawyków behawioralnych, możliwych do skutecznego zastosowania w konkretnych sytuacjach. Aby ludzie mogli wkroczyć do tej nowej dziedziny, przetrwać w niej oraz odnieść korzyść ze swojego przebywania w nowym dla istot biologicznych środowisku niepewnych przedstawień oraz wniosków, które można z nich wysnuć, ludzka zdolność poznawcza musiała wypracować kognitywne adaptacje, zdolne rozwiązywać problemy specyficzne dla tej sfery. Ponieważ informacje zdobyte w nowy sposób można było zastosować jedynie w określonym przedziale czasowym, w lokalnych uwarunkowaniach oraz w przygodnie zaistniałych okolicznościach, sukces owej strategii skojarzeniowej zależał od ukształtowania spekulatywnego mechanizmu, który nieustannie lokalizuje, nadzoruje, uaktualnia oraz uzmysławia warunkowe i zmienne granice użyteczności danej grupy kulturowych przedstawień ${ }^{18}$.

17 L. Cosmides i J. Tooby, op. cit., s. 96.

18 Ibidem, s. 105. Mówiąc o „nowym” dla istot biologicznych środowisku informacyjnym, autorzy mają na myśli dziedzinę przygodnie zdobywanych i eksperymentalnie stosowanych wiadomości oraz przedstawień - w przeciwieństwie do ściśle określonego zestawu informacji przydatnych do przetrwania w środowisku i przekazywanych przez gatunkowy instynkt, na których opiera się kognitywna struktura umysłu u pozostatych zwierząt. 
Jak widać, ludzkie struktury poznawcze charakteryzuje szczególnie duży margines niepewności, którego negatywny wpływ na działania jednostek i całych społeczeństw bardzo trudno wyeliminować (mimo „mechanizmów obronnych”, o których piszą kognitywiści $\left.{ }^{\mathrm{T}}\right)$. Struktury te są wrażliwe zwłaszcza na zjawisko narastania błędu, które wynika z procesów myślowych (głównie wnioskowania) łączących ze sobą elementy zgromadzonego w mózgu zasobu danych i które polega na rozprzestrzenianiu się omyłek lub złudzeń:

\Informacyjna pomyłka, która pojawia się w punkcie wyjścia w procedurze wnioskowania [inference program - M. P.], będzie często skutkować błędami na wyjściu tej procedury, które z kolei może stać się punktem wyjściowym następnych intelektualnych procedur. W efekcie obarczone błędem kulturowe przedstawienie zyskuje moc zainfekowania dowolnego zbioru danych, $\mathrm{z}$ którym wchodzi w interakcję $\mathrm{w}$ toku stosowania myślowych procedur, niszcząc użyteczne informacje za pomocą zaraźliwych fal łańcuchowo połączonych pomyłek ${ }^{20}$.

Wydaje się, że człowiek zlagrowany (więzień gułagu lub nazistowskiego obozu, jeśli udało mu się przetrwać wstępną selekcję do komór gazowych) postawiony jest w obliczu takiej właśnie rzeczywistości, której struktura i zasady generowane są przez zbrodniczy i głęboko błędny zamysł oprawców. Już po przeżyciu pierwszych swoich doświadczeń w obozie nie ma on raczej wątpliwości, że intencje twórców i organizatorów tej rzeczywistości były złe; jednak problem polega nie tylko na tym, że musi on w tej rzeczywistości przeżyćer ${ }^{2}$, lecz także i na tym, że logika tego, co

19 Jak piszą Leda Cosmides i John Tooby w cytowanym już studium: „Z tej przyczyny [tj. niepewności zasobów informacyjnych każdego człowieka - M. P.] nowatorska strategia ewolucyjna wykorzystywania informacji warunkowych i ich bardzo efektywnego przetwarzania w celu regulowania zachowań mogła utrwalić się tylko w sytuacji, w której dobór naturalny doprowadził zarazem do stworzenia metod intelektualnej ochrony przed zagrożeniem, jakie stwarzają fałszywe, niewiarygodne, przestarzałe, niezgodne z kontekstem, oszukańcze lub naruszające swój zakres reprezentacje. W tym celu wyewoluowały poznawcze zapory ogniowe [cognitive firewalls - M. P.] - systemy kwarantanny i korekcji błędów w naszych reprezentacjach. Bez wątpienia są one dalekie od doskonałości. Ale bez nich nasza forma mentalności nie byłaby możliwa” (ibidem, s. 105).

20 Ibidem, s. 96.

21 Problem instynktu samozachowawczego i elementarnej motywacji do życia (czy też lęku przed śmiercią) stanowił w gułagu także obiekt „działań eksperymentalnych” na psychice więźniów, efekt końcowy przypominał zaś zjawisko muzułmana w obozach nazistowskich. (Zdarzało się, że więźniowie gułagu żyli i pracowali tylko dlatego, że byli zbyt wyczerpani i psychicznie zniewoleni, by popełnić samobójstwo). Szałamow odnotował następujące spostrzeżenie w związku z samobójstwem swojego współtowarzysza pracy: „zimno mi się zrobiło, gdy odgadłem i zrozumiałem, że ten nocny obiad przysporzył sił sekciarzowi do samobójstwa. To była właśnie ta porcja kaszy, której brakowało mojemu towarzyszowi w pracy, ażeby zdecydować się umrzeć. Czasem człowiek powinien się spieszyć, żeby nie utracić woli śmierci” (W. Szałamow, Cisza, w: Opowiadania kotymskie, t. 1 Pierwsza śmierć, s. 87). 
się wokół niego dzieje, z jednej strony przypomina zwykły, ludzki świat, z drugiej zaś - przekracza wszystkie jego normy w sposób, który dotychczas wydawał się więźniowi niemożliwy. Ma on zatem do czynienia z groteskową hybrydą procedur działania dopuszczalnych w zwykłym, racjonalnie zorganizowanym społeczeństwie (które podległo już procesowi modernizacji i częściowo zerwało z tradycją - co nie jest bez znaczenia) i zjawisk lub zasad całkowicie nienormalnych, które przeczą podstawom moralności i logiki. Nowe traumatyczne doświadczenia każą więźniowi odkrywać niespotykaną dotychczas złożoność rzeczywistości, a logiczne rozumowanie często przeczy świadectwu zmysłów ${ }^{22}$.

Świadectwa byłych więźniów zarówno gułagu, jak i obozów nazistowskich zinterpretowane w perspektywie konstatacji współczesnej antropologii kognitywnej wskazują na to, że systemy totalitarne - jako element epoki nowoczesnej - rozwinęły swoje światopoglądy, swoją ideologię i społeczną praktykę z powodu wrażliwości ludzkich sposobów poznawania i interpretowania świata. Rozwinęły się niejako „w lukach” ludzkiego systemu poznania i jako takie stanowią widome świadectwo jego słabości, podatności na aberracje. Do owych słabości i paradoksów należy między innymi możliwość pojawienia się rozziewu pomiędzy bezpośrednim świadectwem zmysłów a wnioskowaniem. Cosmides i Tooby piszą następująco o źródłach ludzkiego poznania:

\section{》Źródła te mogą obejmować nie tylko informacje od innych ludzi, lecz także wewnętrzne struktury systemowe, takie jak wizualizację, pamięć epizodyczną, przypuszczenia, projekcje, wstępne wnioskowania itd. Stąd też ludzie mogą sformułować wniosek: „Co prawda moje oczy mówią mi coś, ale mój umysł podpowiada coś zupełnie innego”23.}

Ta właśnie dwoistość stała się w wielu wypadkach obiektem opisu autorów - świadków gułagu. Sołżenicyn wspominał następująco spotkanie z „błatniakami” (czyli zwykłymi kryminalnymi więźniami) na jednym z etapów obozowej epopei:

22 Sugestywnie pisał o tym Sołżenicyn: „Aresztowanie - to nagły i rażący przerzut, przewarstwienie, przeskok, z jednego życia do całkiem innego. Po długiej, krętej ulicy naszego życia pędziliśmy szczęśliwie, albo brnęliśmy smutno wzdłuż jakichś płotów, płotów, płotów ze zgniłych desek, suchej gliny, wzdłuż murów z cegieł, betonu, żelaza. Nie zastanawialiśmy się - co kryje się za nimi? Ani okiem, ani domysłem nie staraliśmy się ich przeniknąć - a tam właśnie zaczynał się kraj GUŁag, ręką dotknąć, dwa metry stąd”, „O, jakże inne nam się wydaje - z perspektywy pokoju przesłuchań - nasze dawne życie, jakie w nim widzimy niebezpieczeństwa, jakie dżungle, iście afrykańskie! A uważaliśmy je za takie zwyczajne!” (A. Sołżenicyn, op. cit., s. 10,73).

23 L. Cosmides i J. Tooby, op. cit., s. 69. 
\W jednej chwili pękają i walą się w gruzy wszystkie zasady ludzkich stosunków wzajemnych, do których przyzwyczaiłeś się w życiu. W ciągu całego twego minionego życia - szczególnie przed aresztowaniem, ale także później, a nawet częściowo w trakcie śledztwa - mówiłeś ludziom jakieś słowa, oni zaś odpowiadali ci również słowami i słowa te oddziaływały w jakiś sposób - można było przekonać nimi kogoś, zaprzeczyć czemuś, albo z czymś się zgodzić. Pamiętasz rozmaite przejawy ludzkich postaw - prośbę, rozkaz, wyrazy wdzięczności - ale to, co cię tu raptem spotkało, jest poza kręgiem tych słów i tych postaw. Jako wysłannik zwierzęcych mord ześlizguje się w dół jakaś postać, najczęściej jest to plugawy małolatek, przez co jego chamstwo i bezczelność są trzykroć bardziej obrzydliwe i drobny ten bies szpera w twoich kieszeniach - nie myszkując ukradkiem, lecz tak, jakby to było jego! [...] Ani temu małemu, złośliwemu gryzoniowi, ani tym mordom na górze, nie sposób niczego wyjaśnić słowami, ani odmówić, ani zabronić, niczego u nich nie wyprosisz! To nie są ludzie, zrozumiałeś to w jednej chwili² ${ }^{24}$.

Zarówno w świadectwie Sołżenicyna, jak i autorów, którzy pisali o obozach nazistowskich, ów fakt elementarnego zaprzeczenia (przez logikę faktów) świadectwu zmysłów dotyczy w szczególności relacji pomiędzy ludźmi - z jednej strony w doświadczeniu ofiar, dla których dostrzeżenie w nadzorcy, strażniku lub kapo człowieka mogło się wiązać ze śmiertelnym niebezpieczeństwem, z drugiej - w relacjach o zachowaniu oprawców, którzy potrafili skutecznie zablokować swoje ewentualne dostrzeżenie człowieczeństwa (a tym samym, jakiegokolwiek pokrewieństwa, choćby wspólnoty gatunku) w więźniach.

Jak dowodzą kognitywiści, jednym z problemów ludzkich systemów poznawczych jest również to, że znaczniki selekcji25 informacji stopniowo zanikają w miarę, jak dana informacja utrwala się w naszym systemie poznawczym (choćby przez wielokrotne jej powtarzanie lub demonstrowanie). Natomiast informacja pozbawiona już swoich znaczników selekcji jest przechowywana w systemie poznawczym jako wiarygodny, w pełni uzasadniony element „obiektywnego stanu świata”, przenosząc się na dobre z „pamięci epizodycznej” do „pamięci semantycznej” ${ }^{26}$. Wydaje się, że w ten właśnie sposób światopogląd spójny, lecz oparty na niepewnych przesłankach, subiektywny i silnie zideologizowany (a zarazem negujący wiele kluczowych

24 A. Sołżenicyn, op. cit., s. 291-292.

25 Do znaczników selekcji należą na przykład: źródło informacji, jej wiarygodność, zasięg, ważność, termin przydatności do wykorzystania (zob. przypis nr 16).

26 Zob. L. Cosmides i J. Tooby, op. cit., s. 81. 
elementów kulturowej tradycji) - taki jak bolszewizm lub nazizm - może osiągnąć ten stopień siły i rozpowszechnienia w otoczeniu reprezentantów danego społeczeństwa, że przestaje być odbierany jako ideologia (pewna perspektywa, zawężony punkt widzenia), a staje się „obowiązującym obrazem rzeczywistości”, któremu wszyscy - tak lub inaczej - muszą sprostać ${ }^{27}$.

\section{4.}

Przeczucie dużego znaczenia kulturowo-cywilizacyjnych przemian związanych z systemami autorytarnymi (w Rosji Radzieckiej, w ZSRS, później zaś w III Rzeszy czy faszystowskich Włoszech) obecne było także w polskiej sowietologii i naukach społecznych lat dwudziestych i trzydziestych XX wieku. Niektórzy autorzy wyraźnie dostrzegali to, że pojawienia się w zrewolucjonizowanej Rosji systemu represyjnego w postaci CZK i NKWD oraz skierowania go przeciw własnym obywatelom nie da się wytłumaczyć jedynie właściwą Rosji „biurokratyczno-autorytarną tradycją” lub (co jeszcze bardziej upraszczające) „tradycją wschodnich satrapii” bądź „dziedzictwem opryczniny”. Ściśle rzecz biorąc, pojawiło się przeczucie tego, że podobne wyjaśnienia (łatwe do formułowania w kulturze polskiej, wraz z jej dominującą od dawna tradycją sporu $z$ imperialną Rosją) grzeszą nadmiarem optymizmu i służą łatwemu samouspokojeniu, czyniąc $z$ autorytaryzmu zjawisko regionalne. Jak pisał na przykład socjolog Aleksander Hertz w I93 r roku:

\section{\ Rosja bolszewicka to nie państwo jedno z wielu, choćby nawet szcze- gólnie wyróżniające się ze względu na swoisty ustrój - lecz problem niezmiernie istotny dla naszej współczesności. Wybuch rewolucji rosyjskiej stworzył nie tylko nowy porządek rzeczy w państwie ro- syjskim - wysunął on ponadto przed umysłowością i praktyką świata cały szereg najistotniejszych zagadnieńn ${ }^{28}$.}

27 Dotyczy to nie tylko znanego fenomenu „zarażenia ideologią”. Jak pokazuje Sołżenicyn, wielka jest siła powtarzalności destrukcyjnych praktyk społecznych, które nie muszą wcale być werbalizowane czy stawać się zalecanym elementem jakiejś „obowiązującej ideologii”, aby się szerzyć: „Powinniśmy publicznie potępić samą IDEE rozprawiania się jednych ludzi z drugimi! Milcząc o występku, wpędzając go w głąb ciała, aby tylko nie było go widać - my SIEJEMY go i w przyszłości da on jeszcze tysiąckrotne plony. Nie karząc, nawet nie ganiąc złoczyńców, my nie tyle dbamy o spokój ich nędznej starości - ile raczej wyrywamy spod nóg nowych pokoleń wszelkie podstawy sprawiedliwości. Dlatego to młodzi wyrastają na «obojętnych», to nie jest wina «braków w pracy wychowawczej». Młodzi utrwalają sobie w pamięci, że podłość nigdy w świecie nie podlega karze, zawsze natomiast zapewnia dostatek.

Jak nieprzytulne, jak straszne będzie życie w takim kraju!” (A. Sołżenicyn, op. cit., s. 106).

28 A. Hertz, Inteligencja wobec bolszewizmu, „Droga” 1931, nr 3, s. 193. 
Wśród uzasadnień wyjątkowej roli rosyjskiego porewolucyjnego eksperymentu państwowo-społecznego warto zwrócić uwagę na diagnozę wybitnego polskiego ekonomisty i sowietologa Stanisława Swianiewicza (późniejszego więźnia obozu w Kozielsku), który w swoim studium Lenin jako ekonomi$s t a^{29}$ starał się określić specyficzną rolę, jaką marksizm odgrywał w światopoglądzie Lenina. Jak pisze Marek Kornat, autor książki o początkach sowietologii w Polsce

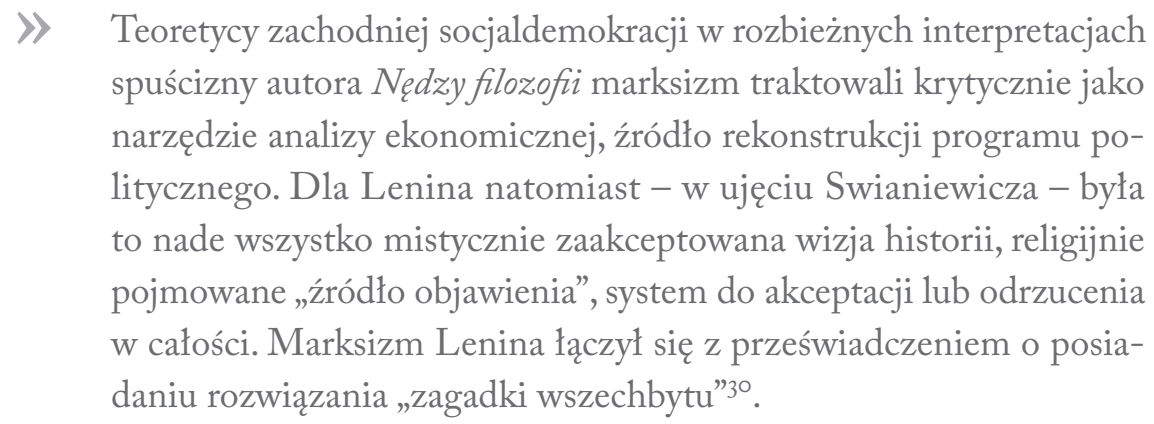

Z tego punktu widzenia łatwiejsza do zinterpretowania wydaje się prekursorska rola leninowskiego bolszewizmu w dziele doprowadzenia do krańców typowo nowoczesnej „wolności” kształtowania relacji międzyludzkich poprzez operowanie sugestywnymi reprezentacjami rzeczywistości oraz odrzucenie wcześniej przyjętych (także niepisanych) norm i ograniczeń. Być może główni aktorzy ówczesnych wydarzeń (po stronie czerwonych) postrzegali swoje działania jako trudną konieczność i po prostu nie widzieli przed sobą innej drogi ${ }^{3 \mathrm{I}}$. Jednak rewolucja podążała nieświadomie torem reformatorskiego ruchu religijnego, $\mathrm{z}$ tą różnicą, że pozbawiona była pozaświatowej sankcji, punktu oparcia poza człowiekiem jako podmiotem absolutnej wolności (w tym wyrażał się jej pierwiastek postoświeceniowy) oraz emocjonalną treścią psychiki zbiorowej w postaci domagającej się zadośćuczynienia społecznej krzywdy, czyli resentymentem (odpowiadającym

29 Zob. S. Swianiewicz, Lenin jako ekonomista, Wilno 1930.

30 M. Kornat, Bolszewizm, totalitaryzm, rewolucja, Rosja. Początki sowietologii i studiów nad systemami totalitarnymi w Polsce (1918-1939), Kraków 2003, s. 237.

31 Jak pisze Sołżenicyn: „W sierpniu 1918 roku, kilka dni przed zamachem Fanny Kapłan, Włodzimierz Iljicz w depeszy do Eugenii Bosz i penzeńskiego gubernialnego komitetu wykonawczego (nie dawano tam sobie rady z powstaniem chłopskim) napisał: «osoby podejrzane (nie „winne” czegokolwiek, lecz podejrzane) zamknąć w podmiejskim obozie koncentracyjnym ». [...] 5 zaś września 1918 roku, dziesięć dni po nadaniu tej depeszy, wydany został Dekret Sownarkomu o Czerwonym Terrorze, podpisany przez Pietrowskiego, Kurskiego i Boncz-Brujewicza. Prócz instrukcji dotyczącej zbiorowych rozstrzeliwań, zawierał on również taką dyrektywę: «zabezpieczyć Republikę Sowiecką przed wrogami klasowymi przez izolowanie ich w obozach koncentracyjnych»" (zob. A. Sołżenicyn, op. cit., s. 360). 
za rosnący „naddatek okrucieństwa” w działaniach rewolucjonistów i ich następców, totalitarnych biurokratów). Jak pisał jeden z przedstawicieli nurtu teologii politycznej Eric Voegelin:

\Społeczność polityczna jest zawsze zintegrowana z ogólnym kontekstem doświadczenia świata i Boga przez człowieka niezależnie od tego, czy sfera polityczna zajmuje podrzędny poziom w boskim porządku hierarchii bytu, czy też sama jest deifikowana. Język polityki zawsze przeplata się z religijnym uniesieniem, a tym samym staje się symboliczny w ścisłym sensie, pozwalając percepcji nakierowanej na doczesną treść świata ulec przeniknięciu przez doświadczenia transcendentalno-boskie ${ }^{32}$.

Zjawiskiem, które zostało odkryte przez rządzące społeczeństwami elity (oraz elity rewolucyjne zmierzające do objęcia władzy) w dobie nowoczesności była natomiast, jak się zdaje, plastyczność metareprezentacji (używając terminologii antropologów kognitywnych) lub przedstawień transcendentnego ładu (według Erica Voegelina ${ }^{33}$ ), ich podatność na kształtowanie oraz przemiany. Wprowadzała ona polityczną ideologię na poziom quasi-religii. Idea ludzkiej wolności formowania wyobrażeń poznawczych - a tym samym sterowania ludźmi lub społeczeństwami, wbrew tradycyjnym normom i zasadom - łączy się z antropocentryzmem i ze szczególną konstytucją podmiotu w kulturowo-filozoficznej tradycji Zachodu. Jednak długofalowy skutek nadużywania tej manipulacyjnej swobody okazuje się taki sam na planie społecznym i indywidualnym. Jest to mianowicie szaleństwo, reprezentowane i symbolizowane przez najcięższą z psychicznych chorób - schizofrenię.

Antropolog kognitywny Christopher Frith w swojej książce Kognitywna neuropsychologia schizofrenii ${ }^{34}$ postulowal istnienie „maszynerii spekulatywnej” (computational machinery), która jest ewolucyjnie wykształconym mechanizmem neuronowym, odpowiedzialnym za koordynację procesu porządkowania i pozycjonowania metareprezentacji (między innymi przyznawanie im odpowiednich znaczników). Ten

32 E. Voegelin, Modernity Without Restraint. The Political Religions; The New Science of Politics; Science, Politics and Gnosticism, wstęp M. Henningsen, Columbia, Missouri 2000, s. 70; oczywiście w przypadku takich politycznych quasi-religii jak komunizm, faszyzm lub nazizm należy - bez żadnej przesady i w sposób wolny od zabobonu - mówić o doświadczeniu demonicznym (którą to kategorią posługuje się również Voegelin).

33 Trzeba jednak pamiętać, że zasadnicza różnica pomiędzy obydwoma tymi ujęciami poznawczych kompetencji człowieka polega na naturalizmie i biologizmie kognitywistyki, pozostającymi w kontraście z mniejszym lub większym (w różnych wersjach tego podejścia) idealizmem teologii politycznej. Metareprezentacja kognitywistów tym się różni od reprezentacji transcendentnego ładu u Voegelina, że prezentuje ona to, co inni ludzie uważają za świat, nie będąc odzwierciedleniem obiektywnie istniejącego, wyższego ładu rzeczywistości.

34 Ch. Frith, The cognitive neuropsychology of schizophrenia, New York 1992. 
właśnie mechanizm, zdaniem Fritha, ulega dekompozycji w schizofrenii, co skutkuje bardzo silnymi zaburzeniami w dziedzinie komunikacji społecznej chorego. Jedynie pobieżnie można przypomnieć w tym miejscu rolę, jaką w rozwoju nowoczesnej psychologii (zwłaszcza w wieku XX) odegrała analiza przypadków schizofrenii, a w szczególności jednego z nich - choroby psychicznej sędziego Daniela Paula Schrebera, kazusu szczególnie ważnego ze względu na jego symptomatyczny dla nowoczesności charakter ${ }^{35}$. O „przypadku Schrebera” pisali najwybitniejsi badacze ludzkiej psyche w XX wieku: Zygmunt Freud, Jacques Lacan, filozof Gilles Deleuze i psychiatra Félix Guattari. Dla Freuda - pisząc w skrócie, a tym samym upraszczając - „przypadek Schrebera” stanowił pewien kłopot (ze względu na niechęć Freuda do psychoz i jego koncentrowanie się na neurozach) i ostatecznie został przez wiedeńczyka opisany jako postać wypartego homoseksualizmu, dla Lacana zaś stał się jednym z modelowych dowodów rozpoznanej przez niego, kluczowej roli „Imienia Ojca” w strukturze uniwersum symbolicznego. Najciekawsze bodaj rozwiązanie tego problemu zaproponowali Deleuze i Guattari. „Przypadek Schrebera" okazał się dla nich oczywistym dokumentem możliwości ukształtowania ludzkiej psyche poza - akcentowanym tak silnie przez Freuda - odniesieniem do „trójkąta rodzinnego” („mama-tata-ja”) i w powiązaniu z mikrobiologiczną organizacją ludzkiego ciała (na którym to poziomie powstaje i działa psychoanalityczne pragnienie i gdzie pierwiastek mechaniczny struktury ludzkich tkanek łączy się $\mathrm{z}$ organicznym, a życie sąsiaduje z martwą materią $\left.{ }^{36}\right)$. Schizofrenia sędziego $\mathrm{Da}-$ niela Paula Schrebera ukazała niejako alternatywny sposób organizacji ludzkiej nieświadomości (względem sfery emocjonalnej duszy) współmierny z filozoficzną konstytucją autorytarnego podmiotu doby Oświecenia, całkowicie wolnego od uwarunkowań społecznych czy więzów rodzinnych.

Wątki zarówno rzeczywistości schizofrenicznej, jak i gruntownego zerwania więźnia $\mathrm{z}$ rodziną i bliskimi pojawiają się często $\mathrm{w}$ literackich świadectwach $\mathrm{z}$ obozów pracy i zagłady. Jak pisał Sołżenicyn: „rzeczywiste granice ludzkiej równowagi umysłowej zakreślone są ciasno i wcale niepotrzebne są dyby albo ruszta, żeby przeciętnego człowieka doprowadzić do stanu niepoczytalności”37. Autor Jednego dnia Irwana Denisowicza przytacza liczne przykłady sytuacji albo metod stosowanych przez NKWD i radziecki kontrwywiad po to, aby indukować schizofreniczną perspektywę widzenia świata u aresztantów lub więźniów, zderzając ich zmysły

35 Kompleksowe i bardzo interesujące omówienie „przypadku Schrebera” zawiera książka Krzysztofa Wolańskiego Sędzia Schreber. Bóg, nerwy i psychoanaliza (Warszawa 2012).

36 Zob. G. Deleuze, F. Guattari, Anty-Edyp. Kapitalizm i schizofrenia, tłum. T. Kaszubski, Warszawa 2017; właściwie cała „schizoanaliza” Deleuzea/ Guattariego (przeciwstawiona przez autorów psychoanalizie Freuda) oraz ich teoria „maszyn pragnienia” ufundowane są na „przypadku Schrebera”.

37 A. Solżenicyn, op. cit., s. 66. 
i emocje z sytuacjami nie do wytrzymania dla normalnego człowieka ${ }^{38}$. Często w rzeczywistości obozowej zdarzały się bowiem sytuacje, które przekraczały granice groteski, dowodząc jakby obecności swoistego czarnego humoru patronującego działaniom oprawców ${ }^{39}$ :

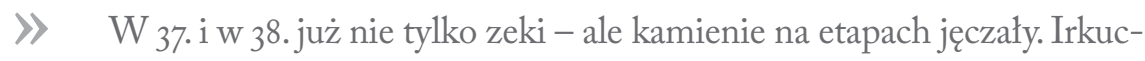
kie tranzytowe - też niczym osobliwym się nie wyróżnia, a tymczasem w 38. lekarze nie ośmielali się zajrzeć do celi. Szli korytarzem, a klucznik krzyczał koło każdych drzwi: „Kto zemdlał - niech wychodzi!”^^.

O ile powyższy przykład można byłoby potraktować jako działanie wymuszone obecnością potężnej fali więźniów docierających do irkuckiego zakładu przejściowego z różnych zakątków kraju, to odnotowane przez Sołżenicyna przypadki groteskowej familiaryzacji gułagu odbierane były przez więźniów jako sadystyczna ironia (nawet jeśli w ten sposób nie zostały zamierzone). Oto przypadek z Wysp Sołowieckich:

\} \text { Przed komendą obozu - klomb, widnieje na nim sympatyczny słoń: } czaprak jego zdobi litera „U” - razem to znaczy U-SŁON (Uprawljenije Sołowieckich Łagierej Osobowo Naznaczenia, czyli zarząd

38 Wystarczy przytoczyć znane fragmenty dzieła Sołżenicyna: „Trzeba jednak wyrazić ORGANOM zasłużone uznanie: podczas gdy dziś przemówienia i sztuki teatralne wydają się - podobnie jak konfekcja damska - dziełem jednej sztancy, rodzaje aresztowań cieszą swoją rozmaitością. Odprowadzają cię na bok w fabrycznej portierni, gdzie dopiero co pokazałeś przepustkę - i już jesteś złapany, biorą cię ze szpitala wojskowego z temperaturą $39^{\circ}$ (Ans Bernsztejn) i lekarz nie sprzeciwia się temu (a spróbowałby się sprzeciwić!); biorą cię wprost ze stołu operacyjnego, po operacji rany żołądka (N.M. Worobiew, inspektor okręgowego wydziału oświaty - 1936) i ledwie żywego, okrwawionego, pakują do celi (wspomnienia Karpunicza); starasz się (Nadia Lewicka) o widzenie ze skazaną już matką, dają ci je! - a okazuje się, że to konfrontacja i aresztowanie! Zapraszają cię w sklepie «Gastronom» do działu zamówień - i tam cię aresztują: zostajesz aresztowany przez wagabundę, który na wszystkie świętości zaklinał cię, żebyś mu pozwolił przenocować pod twoim dachem; zostajesz aresztowany przez montera, który przyszedł sprawdzić licznik; aresztuje cię rowerzysta, który potrącił cię na ulicy: konduktor w pociągu, kierowca taksówki, rachmistrz kasy oszczędności i bileter w kinie - każdy z nich cię aresztuje, i dopiero po niewczasie możesz sobie obejrzeć głęboko schowaną legitymację koloru bordo" (A. Sołżenicyn, op. cit., s. 13-14).

39 Warto zwrócić uwagę na fakt, że indukowanie choroby psychicznej za pośrednictwem działań represyjnych zostało wyszczególnione - jako działanie podlegające karze - w międzynarodowej Konwencji w sprawie zapobiegania i karania zbrodni ludobójstwa, uchwalonej przez Zgromadzenie Ogólne Narodów Zjednoczonych 9 grudnia $1948 \mathrm{r}$. W jej świetle penalizacji (jako element aktu ludobójstwa) podlega mianowicie „Spowodowanie poważnego uszkodzenia ciała lub rozstroju zdrowia psychicznego członków grupy” (narodowej, etnicznej, rasowej lub religijnej). Zob. Dziennik Ustaw Rzeczpospolitej Polskiej nr 2 z 16 stycznia 1952 r. (http://dziennikustaw.gov.pl/du/1952/s/2/9/1). Do podobnych działań nazistów wobec społeczności żydowskiej na ziemiach polskich należało bez wątpienia łudzenie jej przedstawicieli szansą przeżycia pod warunkiem spełnienia jakichś - wyznaczonych przez oprawców - kryteriów, które jednak wciąż się zmieniały lub zaostrzały.

40 A. Sołżenicyn, op. cit., s. 310. 
Sołowieckich Obozów Specjalnych). Ten sam rebus - na Sołowieckich bonach pełniących rolę pieniędzy w tym borealnym państwie. Jaka milutka, rodzinna maskarada! ${ }^{4 \mathrm{I}}$

Podobne działania sąsiadują - na skali technik wywoływania wrażenia absurdu, groteski, beznadziei - ze wspomnianym już powyżej wymieszaniem elementów przeciętej, nawet mieszczańskiej realności z całkowicie odrealnionymi komponentami rzeczywistości jako Kafkowskiej „maszyny tortur”"

Oto w jaki sposób Imre Kertész relacjonuje swoje przybycie do obozu koncentracyjnego w Buchenwaldzie:

\P Potem minęliśmy wielki pomnik; stał w trawie, na łączce wcinającej się klinem między dwie nitki szosy [...]. Biały cokół i wykuta w tym samym białym, miękkim, ziarnistym i matowym kamieniu rzeźba wydawały mi się nieco prymitywne i jakby niestarannie wykonane. Po paskach wyżłobionych w odzieniu mężczyzny, jego łysej głowie, ale głównie po tym, co robił, od razu można było rozpoznać, że przedstawia więźnia. Pochylona w przód głowa, uniesiona wysoko w tył noga miały oznaczać bieg, a dwie splecione ręce spazmatycznym ruchem podtrzymywały od spodu, przyciskając go do brzucha, niesłychanej wielkości kamień w kształcie sześcianu. W pierwszej chwili patrzyłem na pomnik bez żadnego podniecenia, w taki sposób jak na dzieło sztuki, jak nas uczono w szkole, dopiero potem przyszło mi na myśl, że rzeźba na pewno ma jakiś sens i gdy się zastanowić, nie wróży nic dobrego na przyszłość. Ale już ujrzałem gęste druty, potem otwierającą się między dwoma masywnymi kamiennymi słupami ozdobną żelazną bramę $[. .$.$] przybyłem do obozu koncentracyjnego w Buchenwaldzie { }^{43}$.

Kertész - w zgodzie z poetyką swojej pierwszej książki - nie snuje tu żadnych refleksji na temat faktu obecności tego pomnika przed bramą obozu koncentracyj-

41 Ibidem, s. 371.

42 Być może właśnie ten swoiście patchworkowy charakter realności społecznej państwa totalitarnego odpowiedzialny jest za znany fenomen tzw. nowomowy. Nie chodziłoby zatem - w przypadku nowomowy o świadome modyfikowanie przez propagandzistów znaczeń słów tak, by ich pola semantyczne zamieniły się we własne przeciwieństwa, lecz o ruchomość metareprezentacji instytucji społecznego ładu. Na mocy tych przemieszczeń państwo totalitarne korzysta ze słownika prawno-instytucjonalnego np. monarchii konstytucyjnej, pasożytując na nim, a zarazem zarażając jego terminy własną niestabilnością w sferze społecznych przedstawień (lub - jak powiedziałby psychoanalityk - przemieszczając te terminy i pojęcia od bieguna neurozy ku biegunowi schizofrenii).

43 I. Kertész, Los utracony, tłum. K. Pisarska, Warszawa 2002, s. 57. 
nego (a zatem - jeszcze w przestrzeni „wolności”) oprócz wniosków, które mógłby wysnuć więzień, zmierzający do obozu (,rzeźba [...] nie wróży nic dobrego na przyszłość”). Fakt ten można jednak skojarzyć z pojawiającą się później informacją o chronionym ogrodzeniem dębie - zasadzonym ręką samego Goethego - który znajdował się na terenie obozu ${ }^{44}$. Dziwaczna próba artystycznego uwznioślenia ludobójczych działań poprzez umieszczenie pomnika ludzkiej udręki przed bramą obozu koresponduje $\mathrm{z}$ zachowaniem na jego terenie drzewa, którego dotykał genialny niemiecki poeta; działania te miały zapewne pokazać, że obozy koncentracyjne są wytworem społeczeństwa kulturalnego i szanującego sztukę, wzoru do naśladowania dla innych nacji. (A w każdym razie wyrażały taką świadomość sprawców cierpień i zagłady).

Być może mniej jawnym (lepiej ukrytym) absurdem było nawiązywanie organizatorów radzieckiego gułagu do wzorców społeczeństwa światłego i świadomego, hołdującego kluczowej dla Oświecenia idei postępu. Jak pisze Sołżenicyn na temat łagru na Wyspach Sołowieckich:

》Wyjeżdża ci nagle z kremlowskich wrót jakiś zawadiaka wierzchem na koźle, jeździ na nim z miną dostojnika, i nikt się jakoś z niego nie śmieje. Kto zacz? Dlaczego na koźle? To Diegtiariew, eks-ujeżdżacz. Zażądał konia do dyspozycji, ale koni na Sołowkach za mało, więc dano mu kozła. A za co mu się ten honor należy? Jest kierownikiem Stacji Dendrologicznej. Hoduje się tam drzewa egzotyczne. Tu, na Sołowkach.

Ten jeździec na koźle niech będzie pierwszą postacią ze świata sołowieckiej fantastyki. Na co komu egzotyczne rośliny na Sołowkach, gdzie zwyczajne, racjonalnie prowadzone przez mnichów warzywniki już uległy zniszczeniu, gdzie już brak jarzyn? Otóż drzewa egzotyczne za Kołem Podbiegunowym są tu dlatego, że Sołowki, podobnie jak cała Republika Sowiecka, chcą, aby cały świat uległ przemianie, chcą nadać życiu nowy kształt. Ale skąd nasiona, środki? Ano właśnie: na rozsady dla Stacji Dendrologicznej pieniędzy nie brak, nie ma ich za to na żywność dla drwali (bo żywi się tu ludzi jeszcze nie według normy - tylko proporcjonalnie do posiadanych środków).

44 „W pobliżu naszego obozu, jak się dowiedziałem, znajduje się ważne dla kultury miasto Weimar, o którym uczyłem się w domu, oczywiście: tu żył i tworzył swoje dzieła między innymi także i ten człowiek, którego wiersz zaczynający się od słów «Wer reitet so spät durch Nacht und Wind?» znam na pamięć i który, jak mówiono, własnoręcznie zasadził drzewo - to drzewo, już teraz postarzałe i rozrośnięte, opatrzone tablicą pamiątkową i ogrodzone przez nas, więźniów, znajduje się gdzieś na terenie obozu" (ibidem, s. 59). 
Albo te poszukiwania archeologiczne? Owszem, mamy tu Komisje Wykopalisk. Bo pragniemy wiedzieć wszystko o naszych dziejach ${ }^{45}$.

Przyczyną tego, że - z perspektywy czasu - Stacja Dendrologiczna i Komisja Wykopalisk sąsiadujące z ludobójczym Obozem Specjalnym na Wyspach Sołowieckich wydają się bardziej zachowywać swoiste decorum niż przypadek z Buchenwaldu, jest zapewne odkryty w późnej nowoczesności i potwierdzony przez myślicieli postmodernistycznych związek pomiędzy „ideologią Oświecenia” a totalizmem ${ }^{46}$.

5 .

Funkcjonowanie w realności patchworkowej oraz bezustanne doświadczanie granicy ludzkiej zdolności pojmowania powodowało u ludzi zlagrowanych blokadę ekspresji, niezdolność porozumienia się z ludźmi z wolności, nawet jeśli należeli oni do najbliższej rodziny. Podobnie jak wcześniej sędzia Schreber, który nie był w stanie przekazać swoim słuchaczom i lekarzom rozstrzygających dowodów dotkliwej prawdy własnych urojeń (bardziej dla niego realnej niż obiektywna rzeczywistość, bo poświadczonej przez ekstremalne reakcje własnego ciała), więzień łagru traci zainteresowanie kontaktem ze światem zewnętrznym. Jak deklaruje w rozmowie jeden $\mathrm{z}$ bohaterów opowiadań Warłama Szałamowa:

Powiem wam prawdę [...]. - Lepiej do więzienia. Ja nie żartuję. Nie
chciałbym teraz wracać do swojej rodziny. Tam nigdy mnie nie zro-
zumieją, nie potrafią zrozumieć. Wiem, że to, co dla nich ważne,
to dla mnie głupstwo. To zaś, co ważne dla mnie, to, czego niewiele
mi pozostało nie dane jest im ani zrozumieć, ani odczuć. Przyniosę
im nowy strach jeden do tysiąca strachów przepełniających ich życie.

45 A. Sołżenicyn, op. cit., s. 371.

46 Przyjmując - za Erikiem Voegelinem - tezę, że komunizm i nazizm były nie tylko ideologiami, ale także swoistymi quasi-religiami (a zatem funkcjonowały na tak głębokim poziomie psychologicznego warunkowania, że oba - na swój sposób - wytworzyły przerażającą wersję „nowego człowieka”), należałoby orzec, że o ile w komunizmie figurę pośrednika pomiędzy ruchomymi metareprezentacjami ładu (ideologiami) a psychiką ,wyznawcy” stanowi „polityk-naukowiec-eksperymentator”, to w nazizmie podobnym medium byłby „polityk-artysta”, korzystający z „naukowej” inspiracji oraz eksperymentu jako metody działania. (W sprawie związku nazistowskiej ideologii z paradygmatem polityka-artysty - zob. P. de Man, Ideologia estetyczna, tłum. A. Przybysławski, wstęp A. Warmiński, Gdańsk 2000, s. 239). Charakter wspomnianych wyżej „cytatów” z przedtotalitarnej codzienności na Wyspach Sołowieckich i w Buchenwaldzie potwierdzałby tę diagnozę. 
To, co widziałem człowiek nie powinien widzieć, nie powinien o tym wiedziećc 47 .

W tej sytuacji rolę rodziny zaczynają odgrywać z konieczności współwięźniowie (jeśli tylko przejawiają ludzkie odruchy wobec autora danej relacji ${ }^{48}$ ), ale nie tylko długotrwałe oddalenie od bliskich jest kluczem do zrozumienia braku komunikacji. Ważniejsza jest właśnie odmienność doświadczenia, czego dowodzi fakt, że nawet współwięźniowie okazują się obcy, jeśli (niczym lekarze w dokumentacji „przypadku Schrebera”) po prostu nie są w stanie zrozumieć relacji protagonisty:

》 Jakkolwiek w tym tranzytowym pomieszczeniu niewiele było osób z tajgi, nikt go o nic nie wypytywał, chociaż wszystkim pozostałym sądzona była jedynie ta droga. Oni doskonale to rozumieli i właśnie dlatego nie chcieli niczego wiedzieć o tej nieuniknionej tajdze. Andriejew uznał to za słuszne. To wszystko, co on widział, do niczego nie było im potrzebne. Niczego tu się nie da uniknąć, niczego nie można przewidzieć. Dodatkowy strach - po co? Tu jeszcze byli ludzie, Andriejew zaś był przedstawicielem umarlaków. I jego wiedza, wiedza martwego człowieka, nie mogła im, jeszcze żywym ludziom, do czegokolwiek się przydać ${ }^{49}$.

W tym przypadku nieprzekazywalność doświadczenia Andriejewa wiąże się z jego przebywaniem na granicy życia i śmierci, co Szałamow określa jako swoistą pozycję podmiotu-narratora pisanych przez siebie relacji obozowych i przyczynę szczególnego kształtu artystycznego Opowiadań kotymskich $5^{\circ}$.

Zmierzając ku podsumowaniu rozważań, warto wspomnieć o jeszcze jedynym pojęciu wprowadzonym przez antropologów kognitywnych, które mogłoby się przydać w określaniu swoistego pola zainteresowań literatury obozowej. Jest to mianowicie wprowadzona przez Dana Sperbera kategoria „wyścigu zbrojeń” pomiędzy nadawcami komunikatów a ich odbiorcami (na różnych poziomach komunika-

47 W. Szałamow, Stowo nad trumna, w: idem, Opowiadania kotymskie, t. 2 Artysta topaty, s. 227.

48 Jak pisze Sołżenicyn: „zawsze ma swoją osobną pozycję w tym rachunku - pierwsza cela, w której napotkałeś podobnych sobie, na taki sam los skazanych. Całe życie wspominać ją będziesz ze wzruszeniem, z jakim wspomina się chyba tylko pierwszą miłość. I tych ludzi, którzy dzielili z tobą powierzchnię podłogi i powietrze kamiennego sześcianu w dniach, gdy musiałeś z zupełnie nowej strony spojrzeć na całe swoje życie - tych ludzi wspomnisz jeszcze któregoś dnia, jak najbliższą rodzinę.

Zresztą - w tamtych dniach - oni tylko byli twoją rodziną" (A. Sołżenicyn, op. cit., s. 107).

49 W. Szałamow, Kwarantanna tyfusowa, w: idem, Opowiadania kotymskie, t. 1 Pierwsza śmierć, s. 197.

50 Zob. cytat z Notatek Szałamowa na początku tego szkicu - przypis nr 3. 
cji społecznej), polegającego na dążeniu tych pierwszych do uwolnienia swojego przekazu od kryterium oceny „prawda/fałsz”, tych drugich zaś - do stworzenia takich barier kognitywnych, które uniemożliwiłyby tego rodzaju informacyjną manipulację ${ }^{5 \mathrm{I}}$. Ów wyścig zbrojeń rozwinął się w dziejach gatunku ludzkiego po odejściu od zasadniczej ufności w relacjach międzyludzkich, którą korygować mogły jedynie proste techniki rozpoznawania intencji nadawcy, charakterystyczne dla zakładanej przez kognitywistów psychologii naiwnej ${ }^{52}$. Później zaś - już w czasach historycznych - efekt tego wyczerpującego dla obu stron (nadawców i odbiorców komunikatów) wyścigu mógł być łagodzony przez obecność metareprezentacji ładu (inaczej: systemów wartości), przyjętych jako wspólne przynajmniej w obrębie różnych cywilizacji lub kręgów kulturowych.

Realność przedstawiona w literaturze obozowej obejmuje tak opisany informacyjny wyścig zbrojeń w rozwiniętej już postaci, całkowicie wolnej od wszelkich norm, które mogły go wcześniej ograniczać. Państwo totalitarne stanowi teren nieustannej informacyjnej wojny, a jego przewaga nad przeciwnikami i własnymi obywatelami polega na tym, że stara się zgromadzić w swoim ręku wszystkie atuty w tej rozgrywce: monopol informacyjny, techniki propagandy i inwigilacji, cenzurę, możliwość fizycznej likwidacji wszelkich potencjalnych źródeł kryteriów oceny wiarygodności informacji itd. Stąd też twórczość Sołżenicyna, Szałamowa, Kertésza, Leviego czy Borowskiego pełna jest przykładów tego wyścigu zbrojeń, prowadzonego przez dysponentów władzy prawie do końca, także wobec wycieńczonych do granic więźniów obozów. Jest to przede wszystkim wojna pomiędzy śledczymi a oskarżonymi, pomiędzy więźniami (w gułagu - w szczególności między kryminalnymi a politycznymi), między organami państwa a rodzinami uwięzionych, w której nie ma reguł i ograniczeń, a żadna $\mathrm{z}$ form kłamstwa nie jest wykluczona $\mathrm{z}$ arsenału tych zmagań.

Okazuje się jednak, że w sytuacji całkowitego braku atutów po stronie represjonowanych paradoksalne znaczenie zyskuje możliwość odwołania się do podstawowych zdolności człowieka, funkcjonujących na poziomie - chciałoby się powiedzieć „Zwierzęcym”. Sołżenicyn poświęca na przykład obszerny passus swojego dzieła własnej intuicji rozpoznawania nasłanych przez NKWD kapusiów (zwanych stukaczami), która nigdy go nie zawiodła w trakcie odsiadywania całego długoletniego wyroku w obozach na Dalekiej Północy ${ }^{53}$. Wydaje się również, że fakt, iż natura

51 Zob. D. Sperber, Metareprezentacje w perspektywie ewolucyjnej, w: Metareprezentacje. Perspektywa interdyscyplinarna, s. 136.

52 W sprawie tych kategorii zob. ibidem, s. 133.

53 „Mijały lata, leżałem na tych samych narach, maszerowałem w tym samym szeregu, pracowałem w tych samych brygadach z wieloma setkami ludzi i zawsze to tajemnicze oko magiczne, którego istnienie nie było żadną moją zasługą, wprawiało się samo w ruch, zanim jeszcze pomyślałem o nim, zaczynało działać na wi- 
(rośliny, zwierzęta, sklepienie nieba) były dla więźniów gułagu właściwie jedynymi źródłami spokoju, stałości (a nawet czasem pewnego typu szczęścia), wynikał nie tylko z surowych warunków ich bytowania oraz położenia geograficznego obozów ${ }^{54}$. Dowodzi on raczej tego, że ład i stałość - w warunkach całkowitego rozchwiania wyobrażeń dotyczących społeczeństwa - były poszukiwane i odnajdywane przez więźniów właśnie tam.

Podsumowując powyższe rozważania, należałoby stwierdzić, że proponowana tu interdyscyplinarna definicja literatury lagrowej i łagrowej opierałaby się na łączeniu tych ekstremalnych instytucji i zjawisk społecznych z istotowymi cechami epoki nowoczesności. W utworach Sołżenicyna, Szałamowa oraz innych piszących świadków gułagu i obozów koncentracyjnych można znaleźć wiele dowodów na to, że takie zjawiska jak na przykład ruchomość metareprezentacji (i związane z nią rozchwianie kryteriów oceny kluczowych dla przetrwania informacji), rzeczywistość patchworkowa (składająca się z elementów możliwej do uzasadnienia, prawomocnej tradycji oraz absurdalnych, nieludzkich eksperymentów psychologicznych i społecznych) czy wyścig zbrojeń pomiędzy nadawcami i odbiorcami informacji eksplodowały w sposób zupełnie niekontrolowany w realności społecznej XX wieku. Co więcej, zjawiska te łączyły rzeczywistość obozów (uchwyconą w literackich relacjach) z tym kształtem nowoczesnych społeczeństw, który - dzięki swojej wrażliwości rozpoznawali pisarze jeszcze u progu czasów pogardy. Ich osiągnięcia artystyczne, łączone z różnorakimi nurtami literackiego eksperymentu, były zatem w tej samej mierze rezultatem artystycznej przenikliwości i trafną diagnozą, co symptomem bardzo niebezpiecznych czasów, w których gatunek homo sapiens mierzy się ze swoimi najistotniejszymi słabościami i ograniczeniami.

\section{BiBLIOGRAFIA:}

Cosmides L. i Tooby J., Rozważanie źródet - o ewolucji ludzkich zdolności adaptacyjnych do segregowania informacji i tworzenia metareprezentacji, w: Metareprezentacje. Perspektywa interdyscyplinarna, red. D. Sperber, Oxford 2000;

De Man P., Ideologia estetyczna, tłum. A. Przybysławski, wstęp A. Warmiński, Gdańsk 2000;

dok ludzkiej twarzy, oczu, przy pierwszych dźwiękach głosu - i albo kazało mi otwierać się przed tym człowiekiem na oścież, albo tylko uchylać mu szparki, albo zamykać się na głucho. Było to zawsze przeczucie tak nieomylne, że wszystkie gorączkowe zabiegi pełnomocników operacyjnych dookoła werbunku konfidentów zaczęły mi się wydawać mysią krzątaniną: przecież to, że człowiek podjął się roli zdrajcy, zawsze odbija się wyraziście na twarzy, w głosie; niektórzy osiągnęli już, zdawałoby się, wyjątkową zręczność w kamuflażu, a jednak - coś nieczystego wychodzi na jaw. [...] Mam za sobą osiem lat więzienia, trzy lata zesłania, jeszcze sześć lat nielegalnego pisarstwa [...] - i w ciągu tych całych siedemnastu lat zwierzałem się nieostrożnie dziesiątkom ludzi - i ani razu się nie potknąłem! - Nigdzie nie czytałem o czymś podobnym [...] Wydaje mi się, że takie wewnętrzne dyspozycje ma wielu z nas, ale jako wychowankowie epoki racjonalizmu i techniki, lekceważymy tę cudowną właściwość i nie pozwalamy jej się w nas rozwinąć” (A. Sołżenicyn, op. cit., s. 110).

54 Zob. np. W. Szałamow, Na suchej racji, w: Opowiadania kotymskie, t. 1 Pierwsza śmierć, s. 46 oraz idem, Mężne oczy, w: Opowiadania kotymskie, t. 2 Artysta topaty, s. 340. 
Deleuze G., Guattari F., Anty-Edyp. Kapitalizm i schizofrenia, tłum. T. Kaszubski, Warszawa 2017;

Dziennik Ustaw Rzeczpospolitej Polskiej $\mathrm{Nr} 2$ z 16 stycznia 1952 r. (http://dziennikustaw.gov.pl/ $\mathrm{du} / 1952 / \mathrm{s} / 2 / 9 / 1)$;

Frith Ch., The cognitive neuropsychology of schizophrenia, New York 1992;

Harari Yuval N., Sapiens. Od zwierząt do bogów, tłum. J. Hunia, Warszawa 2017;

Hertz A., Inteligencja wobec bolszewizmu, „Droga” 1931, nr 3, s. 193;

Kertész I., Los utracony, tłum. K. Pisarska, Warszawa 2002;

Kornat M., Bolszewizm, totalitaryzm, rewolucja, Rosja. Początki sowietologii $i$ studiów nad systemami totalitarnymi w Polsce (1918-1939), Kraków 2003;

Levi P., Czy to jest cztowiek, tłum. H. Wiśniowska, Kraków 2008;

Metareprezentacje. Perspektywa interdyscyplinarna, red. D. Sperber, Oxford 2000;

Sołżenicyn A., Archipelag GUŁag. 1918-1956, tłum. J. Pomianowski (pseud. Michał Kaniowski), wyd. 14, t. 1-3, Poznań 2018;

Sperber D., Explaining culture. A naturalistic approach, Oxford 2005;

Metareprezentacje w perspektywie ewolucyjnej, w: Metareprezentacje. Perspektywa interdyscyplinarna, red. D. Sperber, Oxford 2000;

Swianiewicz S., Lenin jako ekonomista, Wilno 1930;

Szałamow W., Opowiadania kotymskie, t. 1 Pierwsza śmierć, t. 2 Artysta topaty, tłum. J. Baczyński, Poznań 2017;

Nowa proza. Zapiski z lat siedemdziesiatych („Nowyj mir” 1989, nr 12, wydała I. P. Sirotinskaja), tłum. I. Migal, „Teksty Drugie” 2009, nr 5 (119);

Tyrowicz A., Światto wiedzy zdeprawowanej: idee niemieckiej socjologii i filozofii (1933-1945), Kraków 2009;

Voegelin E., Modernity Without Restraint. The Political Religions; The New Science of Politics; Science, Politics and Gnosticism, wstęp M. Henningsen, Columbia, Missouri 2000;

Wolański K., Sędzia Schreber. Bóg, nerwy i psychoanaliza, Warszawa 2012;

Wood M., Literature and the Taste of Knowlegde, Cambridge-New York 2005.

SŁowa KLUcze: obóz koncentracyjny, GUŁag, doświadczenie graniczne, literackie świadectwo zagłady, kognitywistyka

\section{МАРЕК ПОНКЦИНСКИЙ}

\section{МАГЕРНАЯ И КОНЦААГЕРНАЯ АИТЕРАТУРА: К МЕЖАИСЦИПАИНАРНОМУ ЖАНРОВОМУ ОПРЕАЕАЕНИЮ}

В статье преАпринята попытка с новой точки зрения посмотреть на явление Аагерной и концкагерной Аитературы, описывающей опыт пребывания в тоталитарных трудовых магерях и магерях уничтожения (как нацистских, так и советских). А^я этого преАлагается дать жанровое определение такого рода Аитературы с помощью категорий, разработанных преАставителями когнитивной антропологии (Аэном Спербером, $е$ еой Космидес, Ажоном Тооби и Ар.) в применении к опыту, 
пережитому главными героями этих произведений. Используя такие понятия, как «метарепрезентация», «накопмение эпизодической информации», «исходные маркеры репрезентации» или «шизофреническое расстройство ассоциативного аппарата», можно, по мнению автора статьи, определить круг характерных экстремацьных переживаний героев конциагерной и магерной митературы (например, Солженицына, Шаламова, Кертеса), объединяющих их опыт с отрицательными чертами эпохи современности.

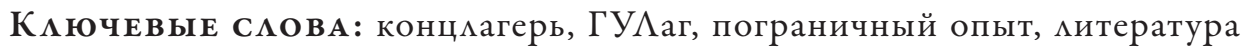
о Холокосте, когнитивистика

\section{Marek Pąkciński}

\section{LABOUR CAMP LITERATURE - TOWARDS AN INTERDISCIPLINARY DEFINITION OF THE GENRE}

The article presents an attempt to look anew at the phenomenon of 'labour camp literature', which describes experiences of the protagonists in totalitarian labour camps or death camps (Nazi as well as Soviet). The endeavour relies on proposing a genological definition of this type of literature, through utilising the categories established by exponents of cognitive anthropology (Dan Sperber, Lena Cosmides, John Tooby, et al.) in relation to the experiences the main characters of these works live through. By making use of notions such as 'meta-representation', 'gathering incidental information', 'source markers of representation', or 'schizophrenic disorder of the association centre', it is possible - according to the author of the article to identify a range of particular, extreme experiences of the protagonists of 'labour camp literature' (for example, the works of Solzhenitsyn, Shalamov, Kertész), connecting their experiences to the negative traits of the modern era.

KEYwords: concentration camp, the Gulag, liminal experience, literary testimony of mass extermination, cognitive studies 